\title{
Osteoporosis Proportion In Stable Patients With Chronic Obstructive Pulmonary Disease
}

\author{
Dwi Handoko', Faisal Yunus ${ }^{1}$, Budhi Antariksa ${ }^{1}$, Rochsismandoko² \\ ${ }^{1}$ Department of Pulmonology and Respiration Medicine, Faculty of Medicine, Universitas Indonesia, \\ Jakarta \\ ${ }^{2}$ Department Internal Medicine, Persahabatan Hospital, Jakarta
}

\begin{abstract}
Background: Chronic obstructive pulmonary disease (COPD) is a major cause of morbidity and mortality in the world. Comorbid diseases in COPD contributing to low health status, affecting the duration of treatment and even death. Osteoporosis is a quite often comorbid that found in COPD. In Indonesia, there are no data of proportion on osteoporosis in patient with stable COPD. The aim this research to get the data of osteoporosis in patients with stable COPD at Persahabatan Hospital.
\end{abstract}

Method: The studie's design was cross-sectional. Patients with stable COPD who came to the Asthma/COPD policlinic at Persahabatan Hospital who meet the criteria of inclusion and exclusion. Subjects had an examined of bone mineral density using dual energy $x$-ray absorptiometry (DXA) and had an examined of vitamin D blood level. At the time of visit, conducted anamnesis of symptoms, exacerbations, history of smoking, used of corticosteroid (oral or inhaled), comorbid, assessment of nutritional status.

Results: Subjects were dominated with male (90.6\%) in the age group 65-75 years old $(53.1 \%)$, and smoking history (84.4\%). The most degree of COPD were GOLD II $(46.9 \%)$ and group B (50\%) that using corticosteroid (65.7\%). Proportion of osteoporosis was $37.5 \%$. There were no statistically significant between COPD group, the degree of COPD, sex, smoking history, history of corticosteroid, age, levels of 25-OHD, pulmonary function with the occurrence of osteoporosis in patients with stable COPD. There were a statistically significant on low BMI as a risk factor for osteoporosis in stable COPD.

Conclusion: The proportion of osteoporosis in patients with stable COPD in the Persahabatan Hospital is $37.5 \%$. There are a statistically significant relationship between BMI with osteoporosis in patients with stable COPD.

Keywords: COPD, osteoporosis, proportion, stable

*Correspondence: Budhi Antariksa - antariksab@gmail.com

Submitted: February 14 $4^{\text {th }}$ 2021, Accepted: February 2th 2021, Published: February $28^{\text {th }} 2021$ 


\section{INTRODUCTION}

Chronic obstructive pulmonary disease (COPD) is a major cause of illness and death in the world. The global burden of disease study estimates that COPD is ranked third in 2020 and fourth in 2030 as the cause of death in the world. In the case of COPD, pain is estimated to increase from fourth to third. The proportion of COPD in the general adult population is estimated at $1 \%$, with a significant increase at age $\geq 40$ years and the proportion continues to increase alongside with age. ${ }^{1}$ Data from the RSUP Persahabatan shows COPD is the fifth rank of outpatient cases and fourth of inpatient cases from 1995-1999.2

Chronic obstructive pulmonary disease may cause a variated severity of emphysema, but it is also may cause other systemic effects and comorbidities. Possible systemic effects from COPD are muscle disorders, cahexia, anemia, autonomic disorders and systemic inflammation. Comorbidities in COPD includes cardiovascular diseases, lung cancer, osteoporosis, diabetes and depression. ${ }^{3}$

Osteoporosis is a systemic bone disease, which has the characteristics of bone density loss resulting in high risk of fracture. Vertebral compression fractures are often found in COPD patients which results in decreased lung function. ${ }^{4,5}$ Comorbid disease in COPD contributes to low health status, affecting length of treatment and death. There has been no research in Indonesia regarding the proportion of osteoporois as a comorbid disease in COPD. This study will discuss the proportion of osteoporosis in stable COPD patients.

The aim this research is investigate the proportion of osteoporosis in patients with stable COPD who visited the asthma/COPD clinic of RSUP Persahabatan.

\section{METHOD}

The design of this study is a observational with cross-sectional study. The study was conducted at the asthma/COPD clinic of RSUP Persahabatan, starting in June 2015 to achieve the specified amount of subjects.

The affordable population are stable COPD patients with mild to severe stable COPD according to the GOLD 2014 criterias who came to the asthma/COPD clinic of RSUP Persahabatan Jakarta.

Subjects were recruited by consecutive sampling, in which every stable COPD patient who met the study criteria and are willing to participate in the study were included until the required amount is achieved. 
After history taking and physical examination, patients were determined their COPD severity from mild to very severe and subsequently selected to look for subjects who meet the criteria for acceptance and rejection. The patient is then asked if they are willing to be the subject of the study by first being given an explanation of the purpose and benefits of the study and the way the examination will be conducted. Patients who are willing to become research subjects were asked to fill out and sign a informed consent.

The acceptance criteria this research are stable COPD patients from mild to very severe, both men and women aged $40-80$ years who came to theasthma/COPD clinic of RSUP Persahabatan Jakarta and willing to voluntarily follow the whole program of research by providing written consent and signing a informed consent. Meanwhile, the rejection criteria are patients with COPD exacerbations and stable COPD patients who are unwilling to continue after agreeing to join.

Stable COPD patients who meet the admission criteria and are willing to be the study subjects will go through anamnesis, physical examination, and blood tests for vitamin $D$ through measurements of serum levels of 25- hydroxy vitamin D (25-OHD) in the Clinical Laboratory Pramita, followed by the gold standard test of osteoporosis DMT using DXA at RSCM Kencana.

\section{RESULT}

This study was a cross sectional study to identify the proportion of osteoporosis in stable COPD patients. This study was conducted from June to September 2015 in stable COPD patients who came to the asthma/COPD clinic of RSUP Persahabatan Jakarta. The number of subjects in this study were 32 people. Subjects were tested for DMT using DXA equipment at RSCM Kencana and vitamin D examination measured by serum 25-OHD levels through venous blood collection in Pramita clinical laboratory.

The study successfully recruited 32 subjects, most subjects were males with a total of 29 subject (90.6\%) compared to women of 3 subject $(9.4 \%)$, as shown in Table 1 . The youngest age is 54.5 years and the oldest is 79.9 years with an average age of $65.78 \pm 6.53$ years. The highest subject age of the group is $65-75$ years as many as 17 people (53.1\%), followed by age <65 years with 14 people (43.8\%) and age $>75$ years with 1 person (3.1\%). 
Table 1. General characteristics and Clinical characteristics of subjects

\begin{tabular}{|c|c|c|}
\hline Characteristics & $n$ & $\%$ \\
\hline \multicolumn{3}{|l|}{ General Characteristic } \\
\hline \multicolumn{3}{|l|}{ Gender } \\
\hline Man & 29 & 90.6 \\
\hline Woman & 3 & 9.4 \\
\hline \multicolumn{3}{|l|}{ Age } \\
\hline$<65$ years & 14 & 43.8 \\
\hline $65-75$ years & 17 & 53.1 \\
\hline$>75$ years & 1 & 3.1 \\
\hline \multicolumn{3}{|l|}{ Education } \\
\hline Elementary school & 10 & 31.2 \\
\hline Middle school & 3 & 9.4 \\
\hline High school & 14 & 43.8 \\
\hline College & 5 & 15.6 \\
\hline \multicolumn{3}{|l|}{ Work } \\
\hline Retired & 9 & 28.1 \\
\hline Private & 19 & 59.4 \\
\hline Not working & 4 & 12.5 \\
\hline \multicolumn{3}{|l|}{ Smoking history } \\
\hline Former smoker & 27 & 84.4 \\
\hline Not a smoker & 5 & 15.6 \\
\hline \multicolumn{3}{|l|}{ Clinical characteristics } \\
\hline \multicolumn{3}{|l|}{ COPD group } \\
\hline A & 2 & 6.3 \\
\hline $\mathrm{B}$ & 16 & 50.0 \\
\hline $\mathrm{C}$ & 3 & 9.3 \\
\hline $\mathrm{D}$ & 11 & 34.4 \\
\hline \multicolumn{3}{|l|}{ Degree of COPD } \\
\hline I & 3 & 9.4 \\
\hline II & 15 & 46.9 \\
\hline III & 10 & 31.2 \\
\hline IV & 4 & 12.5 \\
\hline \multicolumn{3}{|l|}{ Vitamin D levels (25-OHD) } \\
\hline Deficiency & 10 & 31.2 \\
\hline Insufficiency & 11 & 34.4 \\
\hline Sufficiency & 11 & 34.4 \\
\hline \multicolumn{3}{|l|}{ Brink man index } \\
\hline Light & 2 & 6.3 \\
\hline Medium & 11 & 34.4 \\
\hline Heavy & 14 & 43.7 \\
\hline Do not smoke & 5 & 15.6 \\
\hline \multicolumn{3}{|l|}{ Length of COPD } \\
\hline $0-5$ years & 23 & 71.9 \\
\hline$\geq 5$ years & 9 & 28.1 \\
\hline \multicolumn{3}{|l|}{ History of steroid cortico } \\
\hline Without corticosteroids & 11 & 34.4 \\
\hline Inhaled corticosteroids & 21 & 65.6 \\
\hline
\end{tabular}

Note: $\mathrm{COPD}=$ Chronic obstructive pulmonary disease 
Table 1. General characteristics and Clinical characteristics of subjects (cont.)

\begin{tabular}{lcc}
\hline \multicolumn{1}{c}{ Characteristics } & $\mathbf{n}$ & $\mathbf{\%}$ \\
\hline $\begin{array}{l}\text { Use of LABACS } \\
\text { Budesonide/formoterol }\end{array}$ & 10 & 31.2 \\
$(320 \mu \mathrm{g} /$ day) & & \\
Salmeterol/fluticasone & 11 & 34.4 \\
$\quad$ propionate, (500 $\mu \mathrm{g} /$ day) & & \\
Status of Osteoporosis & & \\
$\quad$ Osteoporosis & 12 & 37.5 \\
Osteopenia & 16 & 50.0 \\
Normal & 4 & 12.5 \\
BMI & & \\
Less & 9 & 28.2 \\
Normal & 10 & 31.2 \\
Overweight & 3 & 9.4 \\
Obesity & 10 & 31.2 \\
\hline
\end{tabular}

Note: COPD=Chronic obstructive pulmonary disease; LABACS=long-actingbeta-2 agonist dengan kortikosteroid; $\mathrm{BMI}=$ body mass index

The most prevalent education level of the subjects were high school graduate with 14 people (43.8\%) followed by elementary with 10 people (31.2\%), college with 5 people (15.6\%) and junior high school with 3 people (9.4\%). The most prevalent occupation were private workers with 19 people (59.4\%) followed by 9 retirees $(28.1 \%)$ and unemployed with 4 people (12.5\%). A total of 27 subject were former smokers (84.4\%), and the 5 remaining subjects were non-smoker (15.6\%).

Clinical characteristics appear as in Table 1 , the results of the subject lung pulmonary examination obtained mean $\mathrm{FEV}_{1}$ of $49.49 \pm 16.40 \%$ prediction. The average $\mathrm{FEV}_{1} / \mathrm{FVC}$ was $52.87 \pm 11.46 \%$ prediction. Most of the subjects were group $B$ with 16 people (50\%) followed by group D with 11 people (34.4\%), group C with 3 people (9.3\%) and group A with 2 people $(6.3 \%)$. Most of the research subjects have a COPD degree II or higher based on GOLD 2014, with degree II or moderate degree of 15 people (46.9\%) followed by degree III or severe with 10 people $(31.2 \%)$, degree IV or very severe with 4 people (12.5\%) and degree I or mild 3 people (9.4\%). 25OHD levels were obtained with a mean of $25.45 \pm 8.82 \mathrm{ng} / \mathrm{ml}, 10$ people (31, $2 \%$ ) with deficiency, 11 people (34.4\%) with insufficiency and 11 people (34.4\%) with a sufficient level.

The highest number of IB Brinkman index is severe with 14 people $(43.7 \%)$ followed by moderate with11 people (34.4\%) and mild with 2 people $(6.3 \%)$, the rest are nonsmokers with 5 people (15.6\%). Most subjects suffered from COPD for $0-5$ 
years as many as 23 people (71.9\%) and the remaining had COPD $\geq 5$ years with 9 people (28.1\%). Most subjects had a history of using inhaled corticosteroids as many as 21 people (65.6\%) and 11 people had no history of steroid usage (34.4\%).

Subjects using LABACS budesonide/formoterol 320 $\quad 3 \mathrm{~g} /$ day were 10 people (31.2\%) and salmeterol/fluticasone propionate 500 $\mu \mathrm{g}$ / day as many as 11 people (34.4\%). In the study, the proportion of osteoporosis was $37.5 \%$. DMT status based on the assessment of the lumbosacral and hip areas found 16 subjects with osteopenia (50\%), 12 osteoporosis (37.5\%) and 4 with normal results (12.5\%). BMI calculations based on WHO criteria with Asia modification obtained a mean $21.50 \pm 5.01 \mathrm{~kg} / \mathrm{m}^{2}$, with 9 subjects classified as underweight (28.2\%), 10 normal (31.2\%), 3 overweight (9.4\%) and 1 with obesity (31.\%).

The correlation of subject characteristics with DMT status appears as in Table 2. Age, FEV 1 /FVC, Brinkman index, duration of COPD, and inhaled corticosteroid dose did not differ significantly between osteoporosis, osteopenia and normal DMT groups. Median BMI of osteoporosis group was $16.75(14.00-25.20) \mathrm{kg} / \mathrm{m}^{2}$, with osteopenia subjects of 23.20 (17.30$32.70) \mathrm{kg} / \mathrm{m}^{2}$ and normal subjects of $23.10(19.30-34,20) \mathrm{kg} / \mathrm{m}^{2}$ with $\mathrm{P}=0.029$, this value is significant for the osteoporosis group compared to normal DMT. The $\mathrm{FEV}_{1} \%$ predicted value in osteoporosis group was $45.78 \pm 11.05 \%$ prediction, followed by osteopenia with $48.51 \pm 18.12 \%$ prediction and normal subjects with $64.52 \pm 18.13 \%$ prediction, with significant values for osteoporosis group compared to normal DMT $(P=0.025)$.

Table 4. Correlation of Subject Characteristics with DMT Status

\begin{tabular}{|c|c|c|c|c|}
\hline Characteristics & Osteoporosis & Osteopenia & Normal DMT & $\mathbf{P}$ \\
\hline Age (years) & $66.54 \pm 6.66$ & $64.50 \pm 6.45$ & $68.62 \pm 6.90$ & 0.599 \\
\hline BMI $\left(\mathrm{kg} / \mathrm{m}^{2}\right)$ & $\begin{array}{c}16.75 \\
(14.00-25.20)^{a}\end{array}$ & $\begin{array}{c}23,20 \\
(17.30-32.70)\end{array}$ & $\begin{array}{l}23.10 \\
.30-34.20)\end{array}$ & $0.029^{a}$ \\
\hline Vitamin D (ng/ml) & $25.43 \pm 10.43$ & $23.35 \pm 7.33^{b}$ & $33.92 \pm 4.07$ & $0.013^{b}$ \\
\hline $\mathrm{FEV}_{1}$ (\% prediction) & $45.78 \pm 11.05^{a}$ & $48.51 \pm 18.12$ & $64.52 \pm 18.13$ & $0.025^{a}$ \\
\hline $\mathrm{FEV}_{1} / \mathrm{FVC}$ (\% prediction) & $53.16 \pm 10.06$ & $50.43 \pm 11.79$ & $61.72 \pm 12.43$ & 0.184 \\
\hline Brinkman index (stem/year) & $596.50 \pm 555.72$ & $606.88 \pm 337.20$ & $864.00 \pm 784.57$ & 0.462 \\
\hline Length of COPD (years) & $1(1-15)$ & $2(1-7)$ & $2(1-15)$ & 0.840 \\
\hline $\begin{array}{l}\text { Dosage of inhaled corticosteroids } \\
(\mu \mathrm{g} / \mathrm{day})\end{array}$ & $320(0-500)$ & $320(0-500)$ & $160(0-500)$ & 0.559 \\
\hline
\end{tabular}

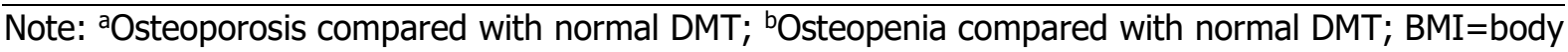
mass index; $\mathrm{FEV}_{1}=$ forced expiratory volume in 1 second; $\mathrm{FVC}=$ forced vital capacity; $\mathrm{COPD}=$ Chronic obstructive pulmonary disease 
The vitamin $D$ level of osteoporosis group was $25.43 \pm 10.43$ $\mathrm{ng} / \mathrm{ml}$, osteopenia was $23.35 \pm 7.33$ $\mathrm{ng} / \mathrm{ml}$, and normal subjects was $33.92 \pm 4.07 \mathrm{ng} / \mathrm{ml}$ with a value of $P=0.013$, this value was significant for the group osteopenia compared with normal DMT. These results are not made as conclusions in the study because the distribution is not evenly distributed in each group, so that to conclude the existing data analysis is divided into osteoporosis and nonosteoporosis groups.

Table 3. Fracture risk according to FRAX

\begin{tabular}{|c|c|c|}
\hline & \multicolumn{2}{|c|}{ FRAX } \\
\hline & Major & Hip \\
\hline Mean & 1.09 & 0.08 \\
\hline Median & 1.05 & 0.10 \\
\hline Standard deviation & 0.32 & 0.06 \\
\hline Minimum & 0.60 & 0.00 \\
\hline Maximum & 2.00 & 0.30 \\
\hline
\end{tabular}

In this study, 10-year fracture risk will be obtained based on FRAX as in Table 3. At the major FRAX group, the mean value is 1.09 and the mean hip FRAX is 0.08 so this value indicates that the risk is greater in the major FRAX group. The median value of major FRAX major is 1.05 and the hip FRAX is 0.10 . The standard deviation of major FRAX is 0.32 and hip FRAX is 0.06. The minimum value of major FRAX is 0.60 and hip FRAX is 0.00 . The maximum major FRAX value is 2.00 and the hip
FRAX is 0.30 . The risk of fracture in the next 10 years appears to be greater overall in major FRAX.

In a study of a total of 32 subjects, the proportion of osteoporosis in stable COPD patients was 12 people (37.5\%) with distribution in each COPD groups as follows group $A$ is 1 person, group $B$ is 5 people, group $C$ is 1 person and group $D$ is 5 people. In the study the proportion of osteopenia is 16 people (50\%) with distribution in each COPD group as follows group A 1 person, group $B 7$ people, group C 2 people and group D 6 people. The proportion of subjects with normal DMT status was 4 people $(12.5 \%)$, all in group $B$. The proportion of osteoporosis appears to be comorbid in stable COPD even in group A, as shown in Table 4.

In this study, osteoporosis in stable COPD patients were distributed in COPD degree II or moderate with 6 people, degree III or severe with 5 people, degree IV or very severe with 1 person and no degree I or mild cases. Osteopenia is distributed in grade I or mild COPD with 2 people, degree II or moderate with 6 people, degree III or severe with 5 people and degree IV or very severe with 3 people. The proportion of subjects with normal DMT status were distributed in first degree or mild COPD with1 person and degree II or moderate with 3 people. The 
proportion of osteoporosis appears mostly in degrees II-III (moderate to severe), as shown in Table 4.

In the study there was no significant relationship between the COPD group with osteoporosis. Distribution of COPD was divided into 2 groups: mild group (group $A+B$ ) and severe group (group $\mathrm{C}+\mathrm{D}$ ). Osteoporosis in the mild group is 6 people (50\%) and in the severe group is 6 people (50\%). Analysis is done by chi-square test, which obtained $\mathrm{P}=0.581$ which means there is no meaningful correlation, as in Table 5.
In this study there was no significant correlation between the COPD degree group with osteoporosis. Distribution of COPD is divided into 2 groups, namely mild group (degree I+II) and severe group (degree III+IV). Osteoporosis in the mild groups were present in 6 people (50\%) and the severe group with 6 people $(50 \%)$. The analysis is done by chisquare test, which obtained $\mathrm{P}=0.581$ showing no meaningful correlation, as in Table 5.

Table 4. The proportion of osteoporosis in stable COPD groups and degree of COPD

\begin{tabular}{lccccccccc}
\hline \multirow{2}{*}{ DMT status } & & \multicolumn{2}{c}{ Osteoporosis } & \multicolumn{2}{c}{ Osteopenia } & \multicolumn{2}{c}{ Normal } & \multicolumn{2}{c}{ Total } \\
\cline { 2 - 9 } & & $\mathbf{n}$ & $\mathbf{\%}$ & $\mathbf{n}$ & $\mathbf{\%}$ & $\mathbf{n}$ & $\mathbf{\%}$ & $\mathbf{n}$ & $\mathbf{\%}$ \\
\hline COPD group & A & 1 & $50.00 \%$ & 1 & $50.00 \%$ & 0 & $0.00 \%$ & 2 & $100.00 \%$ \\
& B & 5 & $31.20 \%$ & 7 & $43.80 \%$ & 4 & $25.00 \%$ & 16 & $100.00 \%$ \\
& C & 1 & $33.30 \%$ & 2 & $66.70 \%$ & 0 & $0.00 \%$ & 3 & $100.00 \%$ \\
Degree of COPD & D & 5 & $45.50 \%$ & 6 & $54.50 \%$ & 0 & $0.00 \%$ & 11 & $100.00 \%$ \\
& I & 0 & $0.00 \%$ & 2 & $66.77 \%$ & 1 & $33.33 \%$ & 3 & $100.00 \%$ \\
& II & 6 & $40.00 \%$ & 6 & $40.00 \%$ & 3 & $20.00 \%$ & 15 & $100.00 \%$ \\
& III & 5 & $50.00 \%$ & 5 & $50.00 \%$ & 0 & $0.00 \%$ & 10 & $100.00 \%$ \\
\multicolumn{1}{c}{ Total } & IV & 1 & $25.00 \%$ & 3 & $75.00 \%$ & 0 & $0.00 \%$ & 4 & $100.00 \%$ \\
& & 12 & $37.50 \%$ & 16 & $50.00 \%$ & 4 & $12.50 \%$ & 32 & $100.00 \%$ \\
\hline
\end{tabular}

Note: $C O P D=C h r o n i c$ obstructive pulmonary disease

Table 5. Correlation between stable COPD and osteoporosis groups

\begin{tabular}{|c|c|c|c|c|c|}
\hline \multirow{2}{*}{ Group } & \multicolumn{2}{|c|}{ Osteoporosis } & \multirow{2}{*}{ Total } & \multirow{2}{*}{$\begin{array}{c}\text { OR } \\
(95 \% \mathrm{CI})\end{array}$} & \multirow{2}{*}{$P$ value } \\
\hline & Yes & No & & & \\
\hline \multicolumn{6}{|l|}{ COPD group } \\
\hline Mild $(A+B)$ & 6 & 12 & 18 & 0.67 & \multirow{2}{*}{$0,581 *$} \\
\hline Severe $(C+D)$ & 6 & 8 & 14 & $(0.16-2.82)$ & \\
\hline \multicolumn{6}{|l|}{ Degree Group } \\
\hline Mild (I + II) & 6 & 12 & 18 & 0,67 & \multirow[b]{2}{*}{$0,581 *$} \\
\hline Severe (III + IV) & 6 & 8 & 14 & $(0.16-2.82)$ & \\
\hline
\end{tabular}

Note: *Chi-square test; COPD=Chronic obstructive pulmonary disease 
Table 6. Correlation between risk factors with osteoporosis in stable COPD patients

\begin{tabular}{|c|c|c|c|c|}
\hline \multirow{2}{*}{ Risk Factors } & \multicolumn{2}{|c|}{ Osteoporosis } & \multirow{2}{*}{$\begin{array}{c}\text { OR } \\
(95 \% \mathrm{CI})\end{array}$} & \multirow{2}{*}{$\mathbf{P}$} \\
\hline & Yes & No & & \\
\hline \multicolumn{5}{|l|}{ Gender } \\
\hline Man & 9 & 20 & 0.31 & \multirow{2}{*}{$0.044^{\mathrm{a}}$} \\
\hline Woman & 3 & 0 & $(0.18-0.53)$ & \\
\hline \multicolumn{5}{|l|}{ Smoking history } \\
\hline Former Smoker & 8 & 19 & 0.10 & \multirow{2}{*}{$0,053^{\mathrm{a}}$} \\
\hline Not a smoker & 4 & 1 & $(0.01-1.09)$ & \\
\hline \multicolumn{5}{|l|}{ Steroid history } \\
\hline Corticosteroids & 9 & 12 & 2,00 & \multirow{2}{*}{$0,465^{a}$} \\
\hline Without corticosteroids & 3 & 8 & $(0,41-9,70)$ & \\
\hline Age (year), mean (SD) & $66.54(6.67)$ & $65.32(6.58)$ & - & $0.618^{\mathrm{b}}$ \\
\hline BMI $\left(\mathrm{kg} / \mathrm{m}^{2}\right)$, median (min-max) & $16.75(14.0-25.2)$ & $23.20(17.3-34.2)$ & - & $<0.001^{\mathrm{c}}$ \\
\hline 25-OHD level $(\mathrm{ng} / \mathrm{ml})$, mean (SD) & $25.43(10.44)$ & $25,47(7,99)$ & - & $0.991^{\mathrm{b}}$ \\
\hline $\mathrm{FEV}_{1} \%$ prediction, mean (SD) & $45.78(11.06)$ & $51.71(18.83)$ & - & $0.330^{\mathrm{b}}$ \\
\hline $\mathrm{FEV}_{1} / \mathrm{FVC} \%$ prediction, mean (SD) & $53.17(10.06)$ & $52,69(12,48)$ & - & $0.912^{\mathrm{b}}$ \\
\hline
\end{tabular}

Note: ${ }^{a}$ Chi square test, ${ }^{b}$ unpaired $T$ test, 'Mann Whitney test

The correlation between risk factors for osteoporosis in patients with stable COPD in this study is shown in Table 6. In the osteoporosis group, 9 were male and 3 were female. In the non-osteoporosis group, all 20 of them were male. After further analysis, we obtained a significant correlation between sex and osteoporosis with a value of $\mathrm{P}=0.044$, but this does not describe the actual population because there were only 3 female subjects.

In the osteoporosis group, 8 were former smokers and 4 were nonsmokers. In the non-osteoporosis group, 19 were former smokers and 1 was a nonsmoker. After analysis, $P=0.053$ was obtained which means there was no significant correlation between smoking history and osteoporosis. In the osteoporosis group, 3 had a history of corticosteroid usage and 9 had no history of steroid usage.

In the non-osteoporosis group, 8 had a history of corticosteroid usage and 12 had no history of steroid usage. After analysis, $\mathrm{P}=0.465$ was obtained showing no significant correlation between corticosteroid history and osteoporosis. The mean age of subjects in the osteoporosis group was $66.54 \pm 6.67$ years while in the nonosteoporosis group it was $65.32 \pm 6.58$ years. After analysis, $\mathrm{P}=0.618$ was obtained showing no significant correlation between age and osteoporosis. In the study, we obtained a median BMI of 16.75 (14.0-25.2) $\mathrm{kg} / \mathrm{m}^{2}$ in the osteoporosis group and $23.20(17.3-34.2) \mathrm{kg} / \mathrm{m}^{2}$ in the nonosteoporosis group. Analysis showed 
$\mathrm{P}<0.001$, revealing a significant correlation between BMI and osteoporosis.

In this study, the mean level of 25OHD for the osteoporosis group was $25.43 \pm 10.44 \mathrm{ng} / \mathrm{ml}$ and $25.47 \pm 7.99$ $\mathrm{ng} / \mathrm{ml}$ in the non-osteoporosis group. Analysis showed $\mathrm{P}=0.991$, revealing no significant correlation between 25-OHD levels and osteoporosis. Value of FEV in osteoporosis group was $45.78 \pm 11.06 \%$ prediction, while in the non-osteoporosis group it was $51.71 \pm 18.83 \%$ prediction. Further analysis resulted is $\mathrm{P}=0.330$ showing no significant correlation between $\mathrm{FEV}_{1}$ and osteoporosis. Value of $\mathrm{FEV}_{1} / \mathrm{FVC}$ was $53.17 \pm 10.06 \%$ in the osteoporosis group and $52.69 \pm 12.48 \%$ prediction in the non-osteoporosis group. After analysis, $\quad \mathrm{P}=0.912$ was obtained showing no significant correlation between $\mathrm{FEV}_{1} / \mathrm{FVC}$ and osteoporosis.

\section{DISCUSSION}

In this study the number of subjects who met the inclusion criteria and participated in this study were 32 people. The basis for calculating subjects in this study was determined based on quantitative data, namely the range of proportion of osteoporosis in stable COPD patients around $9-69 \% .^{6}$ Table 3 describes the correlation of osteoporosis, osteopenia and normal
DMT, but for the statistical analysis used as the conclusion of this study, we divided them into osteoporosis and non-osteoporosis groups as in the following tables. Our study found an osteoporosis proportion of $37.5 \%$ and $50 \%$ if osteopenia. This study supports the finding that the proportion of osteoporosis in COPD is quite high. We found a significant association between BMI and osteoporosis in stable COPD patients. Osteoporosis is a systemic effect in COPD, but the mechanism is still unclear.

This study found a proportion of osteoporosis in stable COPD of $37.5 \%$ which was obtained using the DXA assessment in 2 locations, namely lumbosacral and hip. This result is similar to the study by Karadag et al. who found a proportion of $35 \%$ in outpatient COPD male patients. Our results are in contrast with Sabit et al, who studied 75 subjects of GOLD I-IV COPD using DXA lumbosacral and hip and found a proportion of $24 \% .^{7}$ GraatVerboom et al who studied 554 subjects of COPD GOLD I-IV using DXA wholebody received a proportion of $21 \%{ }^{6}$ Ferguson et al. who studied 658 subjects of GOLD II-IV COPD using DXA lumbosacral and hip received a proportion of $24 \% .^{8}$

Forli et al on 40 COPD subjects who will undergo lung transplantation 
performed DXA lumbosacral and femoral neck and found a proportion of $59 \% .{ }^{9}$ A large-scale study by Sin et al on 5215 subjects of COPD GOLD I-IV using DXA total femur found a proportion of $4-33 \%$. The proportion of osteoporosis depends on the research method used, the study population and the severity of the underlying respiratory disease. The proportion of osteoporosis in COPD varies between 9$69 \%$. Overall, the proportion of osteoporosis is around $35.1 \%$ in COPD patients compared to healthy control subjects. ${ }^{6,10}$ The relative risk of osteoporosis in COPD patients compared to non-COPD is 3.14. ${ }^{11}$

The proportion that we get is quite high, which can be explained because there are 3 female subjects whom all had osteoporosis while the remaining 9 people are male, which affects the proportion obtained. If additional analysis is carried out by removing female subjects, the proportion obtained is still quite high at $31 \%$ compared to the proportion of the general population of women aged 50 80 years in Indonesia by $23 \%$. Other factors that may influence our study group are the mostly elderly age, low BMI, insufficient levels of 25-OHD and moderate-to-severe pulmonary conditions. Low calcium may occur in Indonesian society differently compared to other countries. Calcium intake is mainly from milk, with a calcium content in 100 grams of milk is $143 \mathrm{mg}$. The number of calcium adequacy recommended at the age above 30 years is 1000 mg. Almost all of our subjects drink milk every day. ${ }^{6,12,13}$

Characteristics of subjects seen from the osteoporosis group had an average age of $66.54 \pm 6.66$ years, osteopenia with $64.50 \pm 6.45$ years and normal subjects with $68.62 \pm 6.90$ years. Further analysis revealed no significant correlation. This result is similar to the research conducted by Sabit et al, who found an average age of 65 years, as well as research by Dubois et al. and Dimai et al. In contrast to the study by Katsura et al, they found an average age of 72 years and Forli et al found an average age of 52 years. A majority of our subject are in the age group 65-75 years which is the mean age for the osteoporosis group, this is because most subjects only came for treatment if they had symptoms that interfere with their lives, and they rarely seek treatment on minor complaints. ${ }^{7,9,14-16}$

In the osteoporosis group, there were 9 males and 3 females, while in the non-osteporosis group all 20 of them were males. Analysis showed a significant relationship between sex with osteoporosis in stable COPD but 
because this result does not reflect the actual population thus it cannot be taken as a conclusion of the study. Hattiholi et al also found a high proportion of osteoporosis in the female population. Ferguson GT et al's study found that the proportion of osteoporosis was high in COPD patients regardless of gender. ${ }^{8,17}$

The fact is that women are always in a high risk for osteoporosis idue to the effects of estrogen. Women with osteoporosis are strongly associated with menopause. At menopause, estrogen levels will decrease significantly, and estrogen is known to be important in regulating bone growth and homeostasis. Low esterogen results in an increased proliferation of osteoblasts and osteoclast apoptosis. Low esterogen also results in decreased calcium absorption and decreased calcium reabsorption in the kidneys, resulting in hypocalcaemia and increased parathyroid hormone. All of the above results in bone resorption in osteoporosis.

In this study, from the osteoporosis group there were 8 former smokers and 4 nonsmokers, while in the non-osteoporosis group there were 19 former smokers and 1 nonsmoker. Analysis found no significant association between smoking history with osteoporosis in stable COPD.
Statistically there was no significant relationship, but when viewed from the percentage of osteoporosis groups, most of the osteoporosis patients had a history of smoking. Similar results from Silva et al's study showed no significant relationship between smoking and DMT. ${ }^{18}$

Smoking is included as an independent factor for osteoporosis, the mechanism related to smoking and osteoporosis is not clearly understood though it is assumed to be related to damage to the alveolar tissue and bone structures. The potential mechanism is through influencing the RANK-RANKLOPG system. Smoking has a cumulative dose effect as an independent factor in DMT in the pelvic, vertebrae, lumbar and forearm bones.

This study obtained a history of corticosteroids in the osteoporosis group as many as 9 people using inhaled corticosteroids with a dose of Budesonide/formoterol micrograms/day) and Salmeterol/ fluticasone (500 micrograms/day), and 3 people without corticosteroid usage. After analysis there was no significant relationship between the history of corticosteroids and osteoporosis in stable COPD.

This is in line with the research of Toward a Revolution in COPD Health (TORCH) which did not found a 
significant effect on DMT examined from the placebo group and the group treated with inhaled corticosteroids 2 times a day for 3 years, in which DXA examined the lumboskaral and hip regions. DMT values in the placebo group were $-3.1 \%$, followed by groups of salmeterol $50 \mu \mathrm{g}$ DMT $-1.7 \%$, fluticasone propionate $500 \mu \mathrm{g}$ DMT $-2.9 \%$ and a combination of salmeterol/fluticasone propionate 50 $\mu \mathrm{g} / 500 \mu \mathrm{g}$ DMT $-3.2 \% .^{8,17-19}$

In contrast to the control study in 1780 COPD patients with non-vertebral fractures and 6817 subjects as controls, high doses of corticosteroids $>700$ $\mu \mathrm{g} /$ day were associated with increased fracture risk compared to subjects without inhaled corticosteroids $(\mathrm{OR}=1.68 ; 95 \% \mathrm{CI}=1.10-2.57) .{ }^{17}$

Inhalation corticosteroids are often used in group C and D COPD patients to reduce the frequency of exacerbations and improve quality of life. Oral corticosteroids are used in patients with COPD exacerbations both outpatient and inpatient care with the aim of improving pulmonary function as early as possible. Corticosteroids appear to be independent risk factors for secondary osteoporosis. The fact is that osteoporosis can occur without a history of corticosteroid use. The risk of osteoporosis appears to increase along with the degree of severity, not only from inhaled corticosteroids.

Corticosteroids interfere with osteoblast activity and increase osteoblast apoptosis through inhibition of the $W n t / \beta$-catenin signaling system which is important for osteoblastogenesis.

This study obtained a median BMI of osteoporosis group subjects of 16.75 $(14.0-25.2) \mathrm{kg} / \mathrm{m}^{2}$ while the nonosteoporosis group of 23.20 (17.3$34.2) \mathrm{kg} / \mathrm{m}^{2}$, after analysis a significant association between BMI and osteoporosis in stable COPD was found $(P<0.001)$. The results of this study is similar with that obtained by Forli et al namely BMI of $19.0 \mathrm{~kg} / \mathrm{m}^{2}$ with a $48 \%$ proportion of osteoporosis. ${ }^{9}$ Sabit et al obtained lower results, in subjects with a BMI of $27.6 \mathrm{~kg} / \mathrm{m}^{2}$ they obtained an osteoporosis proportion of $24 \% .{ }^{18}$

Our results found that osteoporosis groups had a BMI that was low or thinner than the nonosteoporosis group. In contrast to Forli et al's research, although BMI is equally lacking, they have a higher proportion of osteoporosis because the subjects had lower lung function. Low body mass index is a key risk factor for low DMT and compression fractures in the future while high BMI is a protective factor of osteoporosis. Fracture risk increased at BMI $<25 \mathrm{~kg} / \mathrm{m}^{2}$, every 1 $\mathrm{SD}$ decrease in age-adjusted BMI increases the risk of fracture by $18 \%$. 
Weight loss or BMI is caused by IL- 6 which stimulates CRP causing skeletal muscle weakness and TNF alpha causes cachexia, skeletal muscle weakness, increased metabolism, increased protein breakdown. This is a systemic manifestation of COPD characterized by elevated levels of IL-6, IL-8, CRP and TNF-a.

The 25-OHD levels were not much different between the osteoporosis group of $25.43 \pm 10.44 \mathrm{ng} / \mathrm{ml}$ and the non-osteoporosis group of $25.47 \pm 7.99$ $\mathrm{ng} / \mathrm{ml}$, and after analysis there was no significant association between 25-OHD levels and osteoporosis in stable COPD. Most of the osteoporosis subjects have vitamin $D$ deficiency. The study subjects with vitamin $D$ deficiency are mostly found in the age of 65-75 years $(60 \%)$, underweight $(40 \%)$ or normal weight $(40 \%)$, history of smoking $(60 \%)$ and severe $(60 \%)$ or moderate (30\%) COPD. ${ }^{19,20}$

Similar results from in Forli et al's study of 46 COPD patients showed a majority of vitamin $D$ deficiency at normal or underweight patients Janssens et al showed vitamin D deficiency in COPD was higher than smokers without COPD, namely $31 \%$ and $60 \%$, which increases along the severity of COPD with $60 \%$ of severe COPD and $77 \%$ of very severe COPD. ${ }^{9,19}$
Vitamin D deficiency is commonly found in the elderly, associated with the risk of osteoporosis and fracture. Vitamin $D$ deficiency is influenced by age, exposure to cigarette smoke, lack of sun exposure, increased vitamin $D$ catabolism due to glucocorticoids, lack of intestinal absorption and poor activation of the liver and kidneys. ${ }^{19}$

Several studies have shown low intake of foods containing vitamin $D$ in COPD patients, especially in the elderly. Vitamin D deficiency causes osteoporosis through a decrease in serum calcium levels which are compensated by an increase in the level of parathyroid hormone then will increase cortisol production. Cortisol increases RANK expression on osteoclast surfaces resulting in bone resorption.

This study obtained $\mathrm{FEV}_{1} \%$ mean prediction of osteoporosis group subjects of $45.78 \pm 11.06 \%$ prediction while the non-osteoporosis group was $51.71 \pm 18.83 \%$ prediction, which after further analysis did not showed a significant relationship between $\mathrm{FEV}_{1} \%$ predictions with osteoporosis in stable COPD. The results of $\mathrm{FEV}_{1} / \mathrm{FVC} \%$ predictions were not much different between the mean of osteoporosis group subjects of $53.17 \pm 10.06 \%$ prediction and non-osteoporosis group by $52.69 \pm 12.69 \%$ prediction, and after 
analysis there was no significant association between $\mathrm{FEV}_{1} / \mathrm{FVC} \%$ predictions with osteoporosis in stable COPD.

This study found that the majority of osteoporosis group subjects had a lower $\mathrm{FEV}_{1}$ level of moderate to severe GOLD criteria, which is in line with the assumption that the risk of osteoporosis increases with the severity of COPD. ${ }^{21}$ The osteoporosis group is mostly in moderate-to-severe COPD degrees and in groups $B$ and $D$ that are often associated with the risk of exacerbations, causing the need of systemic corticosteroids.

Osteoporosis in COPD increases the risk of fracture, if there is a vertebral fracture then $\mathrm{FEV}_{1}$ may be even lower. Osteoporosis therapy is needed to prevent further bone loss and reduce the risk of fracture due to osteoporosis. Most studies showed increased risk of osteoporosis in low $\mathrm{FEV}_{1}$. Jorgensen et al's study on the proportion of osteoporosis in severe COPD $\left(\mathrm{FEV}_{1}<1300 \mathrm{ml}\right.$, an average of $31.4 \pm 7.3 \%$ predictions) associated with glucocorticoid therapy in osteoporosis, found that $68 \%$ of subjects had osteoporosis or osteopenia, however, glucocorticoid usage alone cannot explain the increased proportion of osteoporosis. ${ }^{22}$
In this study there are limitations including the low number of subjects, that we consider may not represent the female population. The study design was cross-sectional so it could not explain the exact results that showed a causal relationship due to osteoporosis in stable COPD. Statistically, there was a significant correlation between BMI as a risk factor for stable COPD but this result could not explain the causal relationship because this study could not know the cause, thus various additional studies and tests are still needed.

\section{CONCLUSION}

The proportion of osteoporosis in stable COPD patients in RSUP Persahabatan Hospital is $37.5 \%$. There were no significant correlation between the stable COPD group or group with osteoporosis as a comorbid factor, but osteoporosis appear as a comorbid factor in stable COPD patients even in group $A$ and GOLD moderate-severe degree. There was no significant association between osteoporosis risk factors, such as gender, smoking history, corticosteroid history, age, 25$\mathrm{OHD}$ level, $\mathrm{FEV}_{1} \%$ prediction and $\mathrm{FEV}_{1} / \mathrm{FVC} \%$ predictions in stable COPD. A significant association between BMI as a risk factor for osteoporosis in stable COPD is found. 
Suggestions from researchers is this research should be carried out with a case control design with a larger number of subjects comparing stable COPD patients with normal smokers and non-smoking patients so that the scores between the two can be obtained. Researcher recommend that stable COPD patients be screened early to detect risk factors for osteoporosis.

\section{REFERENCES}

1. Choudhury G, Rabinovich R, MacNee W. Comorbidities and systemic effects of chronic obstructive pulmonary disease. Clin Chest Med. 2014;35(1):101130.

doi:10.1016/j.ccm.2013.10.007

2. Yunus F. Gambaran penderita PPOK yang dirawat dibagian Pulmonologi FKUI/SMF Paru RSUP Persahabatan. J Respir Indo. 2000;20:64-68.

3. Aryal S, Diaz-Guzman E, Mannino DM. Prevalence of COPD and comorbidity. COPD Comorbidity Eur Respir Monogr. 2013;59:112.

4. Cavaillès A, Brinchault-Rabin G, Dixmier A, et al. Comorbidities of COPD. Eur Respir Rev. 2013;22(130):454-475.

5. Decramer $M$, Janssens $W$. Chronic obstructive pulmonary disease and comorbidities. Lancet Respir Med. 2013;1(1):73-83.

6. Graat-Verboom L, Wouters EFM, Smeen FWJM, Van Den Borne BEEM, Lunde $R$, Spruit MA. Current status of research on osteoporosis in COPD: A systematic review. Eur Respir J. 2009;34(1):209-218.

7. Sabit $\mathrm{R}$, Bolton $\mathrm{CE}$, Edwards $\mathrm{PH}$, et al. Arterial stiffness and osteoporosis in chronic obstructive pulmonary disease. Am J Respir Crit Care Med. 2007;175(12):1259-1265.

doi:10.1164/rccm.200701-0670C

8. Ferguson GT, Calverley PMA, Anderson JA, et al. Prevalence and progression of osteoporosis in patients with COPD: Results from the towards a revolution in COPD health study. Chest. 2009;136(6):1456-1465.

9. Førli L, Halse J, Haug $E$, et al. Vitamin $D$ deficiency, bone mineral density and weight in patients with advanced pulmonary disease. $J$ Intern Med. 2004;256(1):56-62.

10. Sin DD, Anthonisen NR, Soriano JB, Agusti AG. Mortality in COPD: Role of comorbidities. Eur Respir J. $2006 ; 28(6): 1245-1257$.

11. Soriano JB, Visick GT, Muellerova $\mathrm{H}$, Payvandi $\mathrm{N}$, Hansell $\mathrm{AL}$. 
Patterns of comorbidities in newly diagnosed COPD and asthma in primary care.

Chest. 2005;128(4):2099-2107.

12. Setiyohadi B. Osteoporosis. In: Buku Ajar Ilmu Penyakit Dalam. 4th ed. Pusat Penerbitan IImu Penyakit Dalam FKUI; 2007:1259-1274.

13. Hirayama F, Lee AH, Binns CW, Hiramatsu N, Mori M, Nishimura $\mathrm{K}$. Dietary intake of isoflavones and polyunsaturated fatty acids associated with lung function, breathlessness and the prevalence of chronic obstructive pulmonary disease. Mol Nutr Food Res. 2010;54(7):909-917.

14. Dubois EF, Röder E, Dekhuijzen PNR, Zwinderman AE, Schweitzer $\mathrm{DH}$. Dual energy $\mathrm{x}$-ray absorptiometry outcomes in male COPD patients after treatment with different glucocorticoid regimens. Chest. 2002; 121(5):1456-1463.

15. Dimai HP, Domej W, Leb G, Lau $\mathrm{KHW}$. Bone loss in patients with untreated chronic obstructive pulmonary disease is mediated by an increase in bone resorption associated with hypercapnia. $J$ Bone Miner

Res. 2001;16(11):2132-2141.
16. Katsura H, Kida K. A comparison of bone mineral density in elderly female patients with COPD and bronchial asthma. Chest. 2002;122(6):1949-1955.

17. Hattiholi J, Gaude GS. Prevalence and correlates of osteoporosis in chronic obstructive pulmonary disease patients in India. Lung India. 2014;31(3):221-227.

18. Silva DR, Coelho AC, Dumke A, et al. Osteoporosis prevalence and associated factors in patients with COPD: A cross-sectional study. Respir Care. 2011;56(7):961-968.

19. Janssens W, Bouillon R, Claes B, et al. Vitamin $D$ deficiency is highly prevalent in COPD and correlates with variants in the vitamin D-binding gene. Thorax. 2010;65(3):215-220.

20. Heidari B, Javadian Y, Monadi M, Dankob Y, Firouzjahi A. Vitamin D status and distribution in patients with chronic obstructive pulmonary disease versus healthy controls. Casp J Intern Med. 2015;6(2):93-97.

21. Nuti $R$, Siviero $P$, Maggi $S$, et al. Vertebral fractures in patients with chronic obstructive pulmonary disease: The EOLO Study. Osteoporos Int. 2009;20(6):989-998. 
22. Jørgensen NR, Schwarz P, Holme I, Henriksen BM, Petersen LJ, Backer $V$. The prevalence of osteoporosis in patients with chronic obstructive pulmonary disease-A cross sectional study. Respir Med. 2007;101(1):177185. 